$\begin{array}{ll}\begin{array}{l}\text { Australian Journal of } \\ \text { Crop Science }\end{array} & \text { AJCS } \\ \text { AJCS 11(10):1358-1365(2017) } & \text { ISSN:1835-2707 }\end{array}$

\title{
Technological aspects of obtaining spineless cactus [Nopalea cochenilifera (L.) Salm-Dyck] bud flour after drying
}

\author{
Emmanuel Moreira Pereira ${ }^{1}$, Nathan José Pereira da Silva ${ }^{1}$, Hyago Costa de Sousa ${ }^{1}$, Ben-Hur \\ Mattiuz ${ }^{1}$, Carlos Roberto Marinho da Silva Filho ${ }^{1}$
}

${ }^{1}$ São Paulo State University (Unesp), School of Agricultural and Veterinarian Sciences, Jaboticabal-SP, Brazil
${ }^{2}$ Federal University of Paraiba, Center of Human and Agrarian Sciences, Bananeiras-PB, Brazil

*Corresponding author: emmanuel16mop@hotmail.com

\begin{abstract}
The spineless cactus has high production of green matter. Its major importance is utilized for production of flour in agro-industrial processes as well as its nutritional characteristics. The objective of this work was to evaluate the quality of the flour of the spineless cactus bud produced under different temperatures and to describe the drying process by means of mathematical models. The spineless cactus genotype 'Miúda' (Nopalea cochenilifera (L.) Salm-Dyck) was used in this study. The buds approximately with 20 $\mathrm{cm}$ in length were harvested. Drying was carried out at different temperatures $\left(55,65,75\right.$ and $\left.85^{\circ} \mathrm{C}\right)$. Evaluations were done with the application of mathematical models to the data obtained from the drying kinetics, using determination of coefficients $\left(R^{2}\right)$ and chi-square $\left(\chi^{2}\right)$. The chemical and toxicological composition of flour was evaluated. The temperature treatments influenced the flour quality. The flour obtained at the temperature of $55^{\circ} \mathrm{C}$ presented the best chemical percentages and showed no toxic effect. The studied models presented good statistical indices as a function of the adjustments to the experimental data. The Wang and Singh model presented the best $R^{2}$ and $\chi^{2}$ for the drying kinetics of the palm shoots. The Peleg model presented a unique graphical behavior, reaching to cross the field of negative water quantity before reaching the equilibrium point of the dehydration process. Therefore, this model cannot be used to simulate the drying process of 'Miúda' shoots within the studied temperature range.
\end{abstract}

Keywords: Cactaceous; mathematical modeling; Nopalea; quality; toxicity.

Abbreviations: Anvisa_National Health Surveillance Agency; AA_ascorbic acid; $\mathrm{R}^{2}$ _coefficients of determination; $\chi^{2}$ _chi-square;

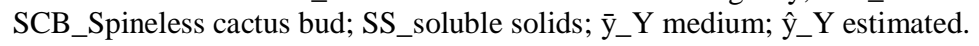

\section{Introduction}

Since the pre-Hispanic period, spineless cactus is being used by humankind in Mexico, assuming a relevant role in the agricultural economy of the Aztec Empire. Along with corn and agave, it is considered as the oldest plant species cultivated in Mexico (Reinolds and Arias, 2008). It is currently distributed throughout the world from Canada (latitude $59^{\circ} \mathrm{N}$ ) to Argentina (latitude $52^{\circ} \mathrm{S}$ ), from sea level to $5100 \mathrm{~m}$ altitude in Peru. This Mexican cactus spread from the Mediterranean to Africa, Asia and Oceania from Europe in 1520 (Hoffmann, 2001). The spineless cactus Nopalea cochenillifera (L.) Salm Dyck is presented as an important alternative for the Brazilian semiarid region due to the great productive potential and its use in human consumption, animal and agro-industrial production. This species produces high phytomass, presenting great potential for the use of desert vegetables in agro-industrial production processes, such as flour production. In this sense, the United Nations Food and Agriculture Organization has recognized the potential of spineless cactus and its importance in the development of arid and semi-arid regions, especially in developing countries, through the economic exploitation of several species with excellent consequences for the environment and for Food security (FAO, 2001).

Spineless cactus or 'Miúda' (Nopalea cochenilifera (L.) Salm-Dyck) is a small-sized plant with a branchy stem. Its cladodium, also called racket, weighs about $350 \mathrm{~g}$ and is almost $25 \mathrm{~cm}$ in length, markedly ovate (apex wider than the base) and bright green in color (Cavalcante et al., 2011).

The chemical composition of the spineless cactus bud varies according to the time of year, species, stage of development, and type of soil (Farias, 2013). The buds contain flavonoids such as kaempferol, isoramnetin and quercetin, all found as aglycones, which are molecules without sugar (Medina-Torres et al. 2011).

Drying cacti buds to produce cacti flour is a technique that not only adds value to the vegetable, but also allows it to be used in several other by-products (Pereira, 2016). However, there are few studies that depict the production of cacti flour from cacti buds at different temperatures with quantification of chemicals and assessment of toxic compounds. The mathematical models commonly rely on external variables, such as temperature and drying air relative humidity (Corrêa et al., 2007). Several mathematical models are used to represent the drying behavior of agricultural products, which can be classified as: theoretical, empirical and semi-empirical (Silva et al., 2004). There are few works in the literature about the production of spineless cactus bud flour. The quantification of its centesimal composition and its toxicity at different temperatures, and performing its drying kinetics by describing it by mathematical models is necessary. This optimizes the technological process of flour production. Due to this need, the objective of this study was to describe the 
technological process involved in the production of spineless cactus bud (SCB) under different temperatures and to apply empirical mathematical models to describe the drying kinetics, determining the chemical and toxicological quality of the obtained flours.

\section{Results and Discussion}

Among the mathematical models (Table 2), the Wang and Singh presented the highest coefficients of determination $\left(R^{2}\right)$ ranging from 0.9980 to 0.9999 and the lowest chi-squares $\left(\chi^{2}\right)$, respectively. This model presented a good data fit to the experimental models, superior to the obtained in the other models (Fig 1A and 1B). The Henderson and Pabis, Lewis, Page, Peleg, and Silva et al. (ii) models fit well to the experimental points of the water content where $R^{2}$ was above 0.98 . Kashaninejad et al. (2007) reported that a coefficient of determination higher than 0.97 represents a good drying process. It was observed that in the adjustment to the model of Wang and Singh the constants $\mathrm{a}$ and $\mathrm{b}$ presented progressive increase as a function of the temperature elevation. This shows the high affinity of the model to the experimental data, being able to be used in the prediction of the drying process in the palm shoot with high degree of confidence within the temperature range worked in this study. Galdino et al. (2016) studying the drying kinetics of atemoia pulp, observed a behavior similar to that of the present study with higher values of $R^{2}$ above 0.9 , for the Page, Midilli and Henderson \& Pabis models in temperature ranges 60, 70 and $80^{\circ} \mathrm{C}$.

The Peleg model presented good statistical indicator, when the data adjustment graphical representation was verified (Fig 2 ). We can verify that it does not present a coherent physical behavior to the study, crossing the negative water index before reaching the dehydration process equilibrium value. This means that the model cannot be used to simulate the drying process of spineless cactus bud within the temperature range studied.

\section{Chemical determinations of cacti buds}

At the initial characterization of spineless cactus bud, they presented high moisture content (above 85\%), carbohydrates and acid $\mathrm{pH}$; low values of protein, lipids, soluble solids, titratable acidity, and ascorbic acid (Table 3). These are attributed to the intrinsic nature of this plant, because it is a desert species rich in water. Corroborating with this work, Farias (2013), Formiga and Costa (2015), Pereira (2016) found similar values in the characterization of spineless cactus bud produced in the arid region of Paraíba, Brazil. Despite they were produced in different locations, the studied buds had similar chemical characteristics.

\section{Proteins}

Spineless cactus bud (SCB) flour had a significant effect (P $<0.05)$ to the percentage of protein as a function of temperature elevation, with the best adjustment to the polynomial model of $\hat{y}=0.243+0.177 x-0.199 x^{2}, R^{2}=$ 0.975 (Fig 3A).

The percentage of protein at SCB flour decreased as temperature increased (Fig 3A). This behavior was also evidenced by Prette (2012) and Sousa et al. (2016), drying of jackfruit at different temperatures. It is a common behavior because most proteins degrade at elevated temperatures, which is dependent on the type of protein. According to
Bobbio and Bobbio (1995), when proteins are subjected to heat treatment they undergo changes in their properties, with destruction of their physiological properties.

\section{Lipids}

A significant effect $(\mathrm{P}<0.05)$ was observed for the percentage of lipids at SCB flour as a function of temperature elevation, with the best fit for the linear model of $\hat{y}=0.755$ $0.280 \mathrm{x}, \mathrm{R}^{2}=0.988$ (Fig 3B). There was a decrease in lipid contents at SCB flour thanks to the heat treatment, a fact that can be attributed to the lipid oxidation, stimulated by the elevation of temperature (Fig 3B).

Gusmão (2011), characterized the cactus pear 'giant' flour, and obtained an average of $3.04 \%$ of lipids in palm cladodes dried at $60{ }^{\circ} \mathrm{C}$. Severo et al. (2015) reviewed the cactus pear flour obtained at different temperatures $\left(70,80\right.$ and $\left.90^{\circ} \mathrm{C}\right)$ and reported values of around $10 \%$ fat. These differences can be attributed to the composition of the plant material, particularly for their age and genotype.

\section{Carbohydrates}

We observed a significant effect $(\mathrm{P}<0.05)$ for the percentage of carbohydrates at SCB flour as a function of temperature elevation, presenting the best fit for the linear model, where $\hat{y}$ $=0.435-0.341 x, R^{2}=0.834$ (Fig 3C).

The SCB flour carbohydrate contents was increased proportionally to temperature increase, ranging from 62 to $72 \%$ (Fig 3C). This result may have been influenced by the decrease of the other centesimal compositions as a function of temperature, since the percentage of carbohydrates is calculated by subtracting the total moisture, lipid, protein, and ash.

Corroborating to this work, Formiga and Costa (2015); Pereira (2016), obtained similar carbohydrate contents, varying from 68 to $73 \%$, when they characterized cactus pear 'giant' bud flour. Borges et al. (2009) observed similar behavior to this study, with increasing percentages of carbohydrates due to the increase of the temperature to banana flour. This behavior is influenced by the loss of water during the drying process.

\section{Ashes}

We observed a significant effect $(\mathrm{P}<0.05)$ with the function of temperature elevation. The best fit for the linear model for this characteristic was $\hat{y}=0.247-0.122 \mathrm{x}, R^{2}=0.847$ (Fig 3D). The ash percentage of SCB flour was decreased with the increased temperature, with values varying from 14 to $18 \%$ (Fig 3D). This behavior may be attributed to the incineration of some mineral compounds present in the vegetable in natura. Gusmão (2011), evaluated the percentage of ash in cacti cladode flour, at different granulometries and obtained indexes varying from 13 to $16.7 \%$. Such results are consistent to those found in this study.

The ash contents varied according to the amount of minerals and/or non-aqueous material present in the sample. It is notorious that the percentage of ash present in the flour of SCB was high, in agreement with the literature data indicating large amounts of minerals such as calcium, iron and phosphorus present in the plant constitution (Pereira, 2016). According to Melo et al. (2003) the high content of ash is justified by the high concentration of mineral elements 
Table 1. Empirical models used to describe the amount of water in SCB.

\begin{tabular}{ll}
\hline Model & Empirical expres \\
\hline Lewis & $\mathrm{RX}=\exp \left(-\mathrm{at}^{\mathrm{b}}\right) \sigma \mathrm{e}^{-\mathrm{at}}$ \\
Henderson and Pabis & $\mathrm{RX}=\mathrm{a} \cdot \exp (-\mathrm{k} . \mathrm{t})$ \\
Wang and Singh & $\mathrm{RX}=1+\mathrm{a} \cdot \mathrm{t}+\mathrm{b} \cdot \mathrm{t}^{2}$ \\
Peleg & $\mathrm{RX}=1-\mathrm{t} /(\mathrm{a}+\mathrm{bt})$ \\
Page & $\mathrm{RX}=\exp \left(-\mathrm{k} \cdot \mathrm{t}^{\mathrm{n}}\right)$ \\
Silva et alii & $\mathrm{RX}=\exp \left(-\mathrm{at}-\mathrm{bt} \mathrm{t}^{1 / 2}\right)$ \\
\hline
\end{tabular}

RX - Moisture rate, without dimensions; T - drying time, h; K, ko, k1 - drying constant, h-1; a, b, c, n - coefficient of the models; Source: Pereira (2016).
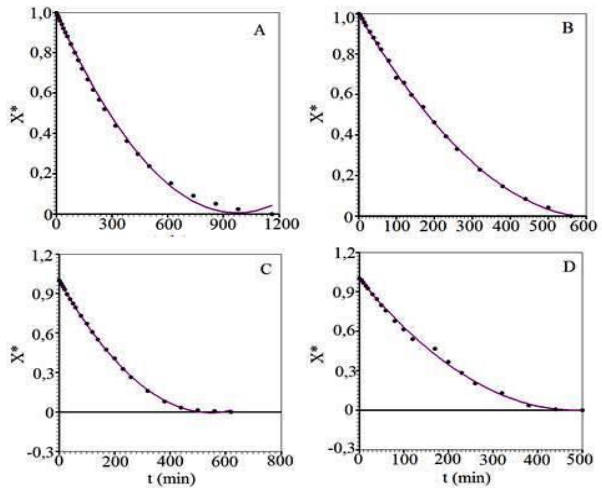

Fig 1. Moisture ratio ( $\left.\mathrm{X}^{*}\right)$ obtained in the drying curve of SCB at $55(\mathrm{~A}), 65(\mathrm{~B}), 75(\mathrm{C})$, and $85^{\circ} \mathrm{C}(\mathrm{D})$, adjusted to the Wang and Singh model.

Table 2. Parameters of adjustment of the models to the experimental data of SCB drying at 55, 65, 75, and $85^{\circ} \mathrm{C}$.

\begin{tabular}{|c|c|c|c|c|}
\hline \multicolumn{5}{|c|}{ Hendeson and Pabis Model } \\
\hline \multirow{2}{*}{$\begin{array}{l}\text { Temperature } \\
\left({ }^{\circ} \mathrm{C}\right)\end{array}$} & \multicolumn{2}{|c|}{ Parameters } & \multirow{2}{*}{$\mathrm{R}^{2}$} & \multirow{2}{*}{$\chi^{2}$} \\
\hline & $\mathrm{a}$ & $\mathrm{b}$ & & \\
\hline 55 & 1.0293 & 0.0027 & 0.9959 & 0.1536 \\
\hline 65 & 1.0415 & 0.0044 & 0.9941 & 0.3309 \\
\hline 75 & 1.0432 & 0.0051 & 0.9899 & 0.3680 \\
\hline 85 & 1.0383 & 0.0057 & 0.9893 & 0.3070 \\
\hline \multicolumn{5}{|l|}{ Lewis } \\
\hline \multirow{2}{*}{$\begin{array}{l}\text { Temperature } \\
\left({ }^{\circ} \mathrm{C}\right)\end{array}$} & \multicolumn{2}{|c|}{ Parameters } & \multirow{2}{*}{$\mathrm{R}^{2}$} & \multirow{2}{*}{$\chi^{2}$} \\
\hline & $\mathrm{a}$ & $\mathrm{b}$ & & \\
\hline 55 & 0.0026 & - & 0.9972 & 0.2218 \\
\hline 65 & 0.0041 & - & 0.9913 & 0.4407 \\
\hline 75 & 0.0048 & - & 0.9925 & 0.4800 \\
\hline 85 & 0.0054 & - & 0.9917 & 0.3885 \\
\hline \multicolumn{5}{|l|}{ Page } \\
\hline \multirow{2}{*}{$\begin{array}{l}\text { Temperature } \\
\left({ }^{\circ} \mathrm{C}\right)\end{array}$} & \multicolumn{2}{|c|}{ Parameters } & \multirow{2}{*}{$\mathrm{R}^{2}$} & \multirow{2}{*}{$\chi^{2}$} \\
\hline & $\mathrm{a}$ & $\mathrm{b}$ & & \\
\hline 55 & 0.009 & 1.1800 & 0.9994 & 0.1940 \\
\hline 65 & 0.009 & 1.2690 & 0.9970 & 0.8115 \\
\hline 75 & 0.0011 & 1.2763 & 0.9975 & 0.8642 \\
\hline 85 & 0.0017 & 1.2181 & 0.9946 & 0.1425 \\
\hline \multicolumn{5}{|l|}{ Peleg } \\
\hline \multirow{2}{*}{$\begin{array}{l}\text { Temperature } \\
\left({ }^{\circ} \mathrm{C}\right)\end{array}$} & \multicolumn{2}{|c|}{ Parameters } & \multirow{2}{*}{$\mathrm{R}^{2}$} & \multirow{2}{*}{$\chi^{2}$} \\
\hline & $\mathrm{a}$ & $\mathrm{b}$ & & \\
\hline 55 & 383.3921 & 0.6142 & 0.9962 & 0.1342 \\
\hline 65 & 279.0796 & 0.4700 & 0.9980 & 0.5655 \\
\hline 75 & 222.1346 & 0.5721 & 0.9935 & 0.2126 \\
\hline 85 & 204.3292 & 0.5381 & 0.9960 & 0.1074 \\
\hline \multicolumn{5}{|l|}{ Silva et alii } \\
\hline \multirow{2}{*}{$\begin{array}{l}\text { Temperature } \\
\left({ }^{\circ} \mathrm{C}\right)\end{array}$} & \multicolumn{2}{|c|}{ Parameters } & \multirow{2}{*}{$\mathrm{R}^{2}$} & \multirow{2}{*}{$\chi^{2}$} \\
\hline & $\mathrm{a}$ & $\mathrm{b}$ & & \\
\hline 55 & 0.0032 & -0.0097 & 0.9972 & 0.7528 \\
\hline 65 & 0.0054 & -0.0167 & 0.9927 & 0.2010 \\
\hline 75 & 0.0062 & -0.0184 & 0.9935 & 0.2263 \\
\hline 85 & 0.0067 & -0.0165 & 0.9920 & 0.2202 \\
\hline \multicolumn{5}{|c|}{ Wang and Singh } \\
\hline Temperature & Paramete & & & \\
\hline$\left({ }^{\circ} \mathrm{C}\right)$ & $\mathrm{a}$ & $\mathrm{b}$ & & $\chi$ \\
\hline 55 & -0.0020 & $0.1053 \times 10^{-5}$ & 0.9981 & 0.6058 \\
\hline 65 & -0.0032 & $0.2560 \times 10^{-5}$ & 0.9995 & 0.1182 \\
\hline 75 & -0.0036 & $0.3368 \times 10^{-5}$ & 0.9997 & 0.7387 \\
\hline 85 & -0.0041 & $0.4217 \times 10^{-5}$ & 0.9980 & 0.4750 \\
\hline
\end{tabular}

$\mathrm{a}, \mathrm{b}=$ constant of the models; $R^{2}=$ coefficient of determination $; \chi^{2}=$ chi-square 

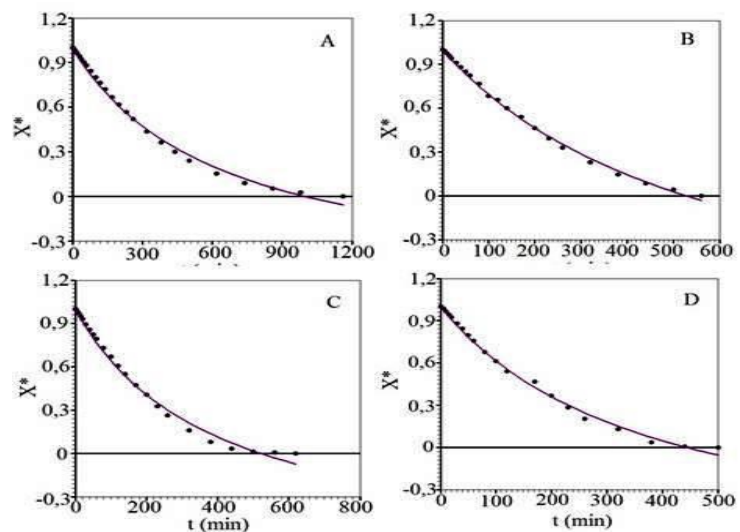

Fig 2. Moisture ratio $\left(\mathrm{X}^{*}\right)$ obtained in the drying curve of SCB at $55(\mathrm{~A}), 65(\mathrm{~B}), 75(\mathrm{C})$, and $85^{\circ} \mathrm{C}(\mathrm{D})$, adjusted to the Peleg model.

Table 3. Mean values and standard deviation of the physico-chemical characteristics of SCB.

\begin{tabular}{lc}
\hline Analytical Determinations & Values \\
\hline Protein (\%) & $0.93 \pm 0.11$ \\
Lipids (\%) & $1.20 \pm 0.20$ \\
Carbohydrates (\%) & $8.24 \pm 0.64$ \\
Ashes (\%) & $2.23 \pm 0.21$ \\
Humidity (\%) & $87.0 \pm 0.50$ \\
Soluble Solids (\%) & $1.10 \pm 0.26$ \\
pH & $4.63 \pm 0.10$ \\
Titratable Acidity (\%) & $1.48 \pm 0.29$ \\
Ácido ascórbico $\mathrm{mg} \mathrm{(100} \mathrm{g)})^{-1}$ & $4.65 \pm 0.79$ \\
\hline
\end{tabular}
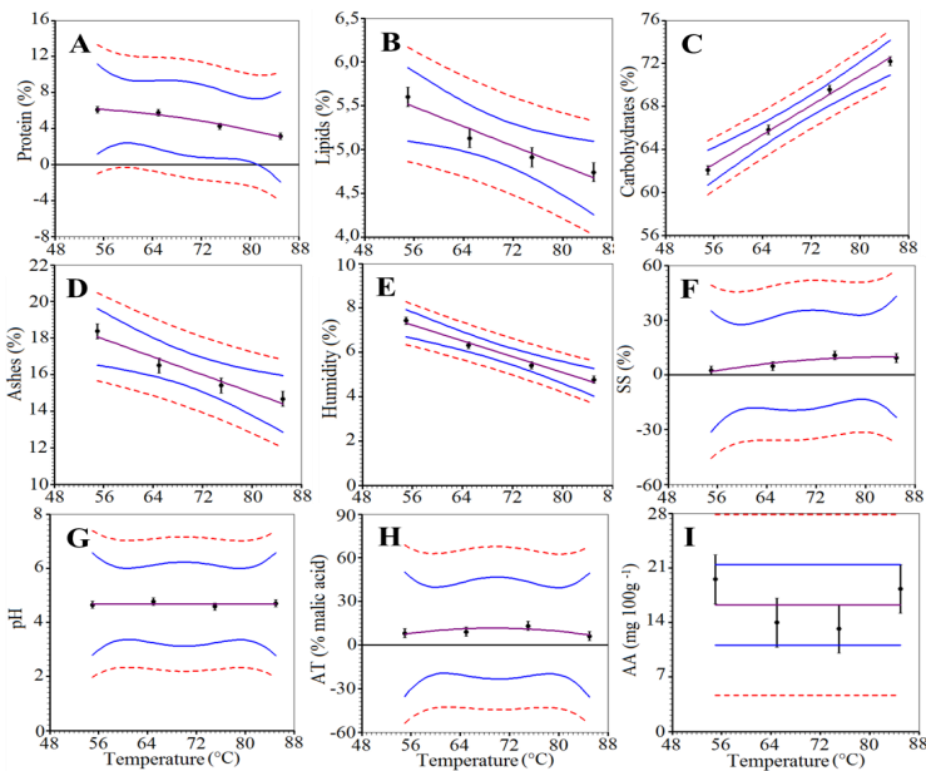

Fig 3. Proteins (A), Lipids (B), Carbohydrates (C), Ashes (D), Humidity (E), Soluble Solids (F), pH (G), Titritable Acidity (H), and Ascorbic Acid (I) in SCB flour at 55, 65, 75, and $85^{\circ} \mathrm{C}$. The central line is the adjusted function to the continuous external lines that define a $95.4 \%$ confidence range. The dashed outer lines define the experimental points prediction range $(95.4 \%$ confidence).

Table 4. Lethal Dose $\left(\mathrm{LD}_{50}\right)$ values and superior and inferior limits in SCB flour.

\begin{tabular}{l|c}
\hline Sample/flour & $\mathrm{DL}_{50}$ \\
\hline $55^{\circ} \mathrm{C}$ & 1236,41 (inferior limit) 452,1704 (superior limit) 2020,6625 \\
\hline $75{ }^{\circ} \mathrm{C}$ & 1072,23 (inferior limit) 1074,2903 (superior limit) 1288,7409 \\
\hline $65^{\circ} \mathrm{C}$ & 1000,70 (inferior limit) 350,9075 (superior limit) 2715,7756 \\
\hline $85^{\circ} \mathrm{C}$ & 999,36 (inferior limit) 188,2125 (superior limit) 2186,9418 \\
\hline
\end{tabular}


that it contains, highlighting the high concentration of calcium.

\section{Humidity}

A significant effect $(\mathrm{P}<0.05)$ was observed for the percentage of moisture of SCB flour as a function of temperature elevation. The best fit for the linear model for this characteristic was $\hat{y}=0.121-0.887 x, R^{2}=0.974$ (Fig 3E).

We observed a decrease in the moisture content in SCB flour as a function of the temperature increase. The difference between the highest and the lowest percentage value was only $2.7 \%$ (Fig 3E). Although the highest moisture content $(7.42 \%)$ was verified in SCB flour at the lowest temperature $\left(55^{\circ} \mathrm{C}\right)$, this content is within the limit of $15 \%$ set by the current legislation (Brazil, 1978). This moisture content has been indicated as maximum for the preservation of SCB flour. Flour moisture is an undesired characteristic as it provides rapid change in the process of material deterioration with high water activity.

Pereira (2016) and Silva et al. (2004) studied the cacti drying and they observed a similar behavior with the reduction of moisture content as a function of temperature increasing, like in this study. This behavior was explained by Reis (2002), stating that when high temperatures are used for drying, the heated air promote heating of the product, increasing the vapor pressure and facilitating the exit of water, decreasing consecutively the moisture percentage of the flour. However, when we choose a drying technique with the lower temperature, it better keeps the organoleptic properties of the product; as well minimizes the energetic consumption.

\section{Soluble Solids (SS)}

We observed a significant effect $(\mathrm{P}<0.05)$ for the percentage of SS in SCB flour as a function of temperature elevation, presenting the best fit for the polynomial model, where $\hat{y}=-$ $0.598+0.166 \mathrm{x}-0.999 \mathrm{x}^{2}, R^{2}=0.870($ Fig 3F).

There was an increase in the concentration of SS as a function of temperature increase, ranging from 2 to $10 \%$ (Fig $3 \mathrm{~F})$. This behavior can be attributed to the water removal thanks to the increase in temperature, leading to the concentration of solutes.

Rodrigues (2006), evaluated drying of pineapple cv. Pearl at temperatures of 60,65 , and $70{ }^{\circ} \mathrm{C}$ with air speed of 0.5 , 0.75 and $1.0 \mathrm{~m} \mathrm{~s}^{-1}$, and observed an increase in soluble solids contents as temperature was raised. Pereira (2016) found the same behavior, evaluating the SS content of SBC flours obtained at different temperatures $\left(50,60,70\right.$ and $\left.80^{\circ} \mathrm{C}\right)$.

The elevation of the SS concentration is a common phenomenon after increasing the temperature for processing of flour which has already been described by other authors. Rodrigues (2006) defined that removal of water promotes the concentration of solutes so that these components are present in larger quantities, per unit mass, in the dehydrated food than in the fresh food.

\section{$p H$}

A significant effect $(\mathrm{P}<0.05)$ was observed for $\mathrm{pH}$ values in SCB flour as a function of temperature elevation, where the best fit for the polynomial model, was $\hat{y}=0.470-0.410 x$ $+0.751 \mathrm{x}^{2}, R^{2}=0.414$ (Fig 3G).

The $\mathrm{pH}$ values varied slightly in the studied temperatures, presenting an average of 4.6 which characterizes the studied material as acid (Fig 3G). Such behavior is desirable, since the acidic $\mathrm{pH}$ inhibits microbiological growth, influencing the flour lifespan.

The results of this study were found by Borba (2005); Borges et al. (2009); Portela (2009), working on sweet potato flour, banana flour and watermelon flour, respectively, in which they found acidic $\mathrm{pH}$ values for the flours. Considering this as a desired behavior, the $\mathrm{pH}$ is a relevant conservation factor; when the environment is acidic according (Pereira, 2016). It restricts much of the growth of pathogenic microorganisms, prolonging the material longevity and maintaining its integrity and quality.

\section{Titratable Acidity (TA)}

There was a significant effect $(\mathrm{P}<0.05)$ for the percentage of TA in SCB flour as a function of temperature elevation, where the best fit for the polynomial model, was $\hat{y}=-0.851-$ $0.278 \mathrm{x}+0.275 \mathrm{x} 2, R^{2}=0.623$ (Fig $3 \mathrm{H}$ ).

The mean for the titratable acidity contents was $0.91 \%$ of malic acid (Fig $3 \mathrm{H})$. It is evident that, in relation to the initial data $(1.48 \%)$, there was AT reduction when the product was dried $(0.91 \%$ of malic acid). This behavior can be attributed to the biochemical reactions that occur when temperature increases, where many organic acids are used as substrate/catalyst in these reactions. Data agree to the $\mathrm{pH}$ ones (Fig 3G) because the flour $\mathrm{pH}$ variations, are accompanied by the TA contents as a function of the temperatures.

Nascimento et al. (2011) characterized palm flour dried under different temperatures $\left(60,70\right.$, and $\left.80{ }^{\circ} \mathrm{C}\right)$ and observed a similar behavior for TA; increasing TA value as temperature was increased.

According to Azevêdo et al. (2008), the TA content determines the quality of flour. For wheat flour the Anvisa (Brazil, 1996) determined a limit of $2 \%$. The TA values found in this work (Fig $3 \mathrm{H}$ ) are in accordance with those established by the Brazilian legislation. A high TA interferes directly with the final product quality.

\section{Ascorbic Acid (AA)}

There was no significant effect for the AA content in SCB flour, presenting $\bar{y}=16.24$ (Fig 3I). Nevertheless, this acid was concentrated 5-fold after drying (Table 3). The AA contents after the first drying at $55{ }^{\circ} \mathrm{C}(19 \mathrm{mg}$ of ascorbic acid $100 \mathrm{~g}^{-1}$ of flour), was progressively reduced until temperature of $75{ }^{\circ} \mathrm{C}\left(13 \mathrm{mg}\right.$ of ascorbic acid $100 \mathrm{~g}^{-1}$ of flour) (Fig 3I). Ascorbic acid is a natural antioxidant, rich in vitamins and also helps in the preservation of processed foods. However, this compound is easily oxidized, losing its antioxidant/vitamin function, when exposed to high temperatures (Gava, 2008). Ordoñes Perdera (2005), reported that when the initial drying is very fast, the water vapor can be eliminated from the surface of the product more quickly than the water that moves from the center of the food. Under these conditions, there may be strong shrinkage of the surface layer, which behaves like a hard and impermeable film, offering strong resistance to subsequent vapor transfer.

Pereira (2016) studied AA values in palm flour dried at different temperatures and observed similar behavior when compared to this work, with a progressive increase of AA values as a function of temperature.

\section{Toxicologic potential evaluation of Miúda Cacti Buds flour}

According to Nguta et al. (2011), both organic extracts and aqueous extracts with $\mathrm{LD}_{50}$ (Lethal Dose) values smaller than 
$100 \mu \mathrm{g} / \mathrm{mL}$ present high toxicity. The $\mathrm{LD}_{50}$ values between 100 and $500 \mu \mathrm{g} / \mathrm{ml}$ presents moderate toxicity, $\mathrm{LD}_{50}$ values between 500 and $1000 \mu \mathrm{g} / \mathrm{mL}$ have low toxicity and $\mathrm{LD}_{50}$ above $1000 \mu \mathrm{g} / \mathrm{mL}$ are considered non-toxic.

In this study, there was reduction of the $\mathrm{LD}_{50}$ as the function of increased temperature. The flours obtained at temperatures of $55^{\circ} \mathrm{C}, 65^{\circ} \mathrm{C}$, and $75^{\circ} \mathrm{C}, \mathrm{LD}_{50}$ showed $\mathrm{LD}_{50}$ higher than 1000 (Table 4), considered as non-toxic, according to Nguta et al. (2011). However, the flour obtained at $85{ }^{\circ} \mathrm{C}$ had an $\mathrm{LD}_{50}$ of 999 and was considered to be of low toxicity. Pereira (2016) studied the toxicity of SBC flour and found a coherent behavior to the one observed in this study. The cacti bud's flour presented a weak toxicity facing Artemia Salina. However, in an in vivo test on mice, the same author found that flour produced by cacti buds is not toxic. According to Pereira et al. (2015), the toxic potential of the substances is mainly linked to their chemical composition, especially in proteins and phenolic compounds.

Cacti flour has high contents of phenolic compounds, especially when it is obtained from drying at high temperatures, where there is an extravasation of the cell membrane releasing in greater number these secondary metabolites (Pereira, 2016).

\section{Materials and Methods}

\section{Experimentation}

The work was developed at the Center for Human, Social and Agricultural Sciences - CCHSA, Campus de Bananeiras, belong to the Federal University of Paraíba (Brazil), in the Laboratory of Seed Technology and Physical Chemical Analysis.

\section{Plant materials}

The Spineless cactus species (Nopalea cochenillifera (L.) Salm-Dyck) was used, with great productive potential. The sprouts used came from $80 \mathrm{~m}^{2}$ of experimental area belong to the CCHSA, where the cladodes were produced in a densified form with spacing of $0.5 \mathrm{~m}$ between plants and $1.80 \mathrm{~m}$ between rows.

\section{Preparation of the samples}

The buds with $\sim 20 \mathrm{~cm}$ length were harvested at 7 o'clock and then taken to the Seed Technology Laboratory under controlled temperature conditions $\left(20{ }^{\circ} \mathrm{C}\right)$. Buds were selected based on appearance and size, and bud with lesions longer than $20 \mathrm{~cm}$ were eliminated, aiming to improve the uniformity of the samples and to remove the coarse soils adhered to the surface. They were cut and standardized with the same size of $97.8 \times 43.3 \mathrm{~mm}$ (Width $\mathrm{x}$ Length). The bud were sliced with the aid of a Robot Coupe ${ }^{@}$ industrial processor, obtaining final rectangular format with dimensions of $97.8 \times 10 \times 2 \mathrm{~mm}$ (Width $\times$ Length $\times$ Thickness). The sanitization process was carried out in three stages. In the first stage, the shoots were submitted to sanitization in a solution of $200 \mathrm{mg} \mathrm{L}^{-1}$ of free chlorine (Sumaveg ${ }^{\mathrm{TM}}$ ) in water containing ice $\left( \pm 1^{\circ} \mathrm{C}\right)$ for $10 \mathrm{~min}$. The rinsing was carried out with water containing $5 \mathrm{mg} \mathrm{L}^{-1}$ free chlorine (Sumaveg $^{\mathrm{TM}}$ ) and ice for $10 \mathrm{~min}$. Then the shoots were drained for $1 \mathrm{~min}$ in a centrifuge $\left(\mathrm{Consul}{ }^{\mathrm{TM}}\right.$ model $\mathrm{C} 2 \mathrm{~A} 05 \mathrm{BB}$, at $2800 \mathrm{rpm})$.

\section{Flour production}

After the minimum processing, the shoots were submitted to drying in a drying oven with circulation and forced renovation (Solab TM, model SL 102/42) in four different temperatures $\left(55,65,75\right.$ and $\left.85^{\circ} \mathrm{C}\right)$. They were placed in cast stainless steel forged trays measuring $15 \mathrm{~cm}$ in length, 10 $\mathrm{cm}$ in thickness and $5 \mathrm{~cm}$ in depth. In each tray around $100 \mathrm{~g}$ of plant material were used, previously weighed in a semianalitic scale $\left(\right.$ Bell $^{\mathrm{TM}}$, model SSR-600, with 2 decimal places, and accuracy of $0.5 \mathrm{~g}$ ), containing seven replicates of each, in all temperatures. The weighting was carried out continuously, counting from time 0 until reaching the constant weight.

\section{Kinetics of drying}

Experimental data were expressed as the moisture ratio (RU *), as described in Eq. 1.

$$
R U^{*}=\frac{U-U_{e}}{U_{i}-U_{e}}
$$

Where:

$\mathrm{U}$ - moisture content of the product, bs .;

Ui - initial moisture content of the product, bs .; and

$\mathrm{Ue}$ - equilibrium moisture content of the product, bs.

To adjust the dehydration curves, the mathematical models of cacti bud to the experimental (empirical equations) described in Table 1 were used.

To adjust the experimental data we used the software program Lab Fit for curve fitting (Silva and Silva, 2015). The evaluation criteria to choose the best model were coefficient of determination $\left(\mathrm{R}^{2}\right)$ and the chi-square $\left(\chi^{2}\right)$, calculated by the Eq. 2.

$$
\chi^{2}=\sqrt{\sum\left(X_{\exp }^{*}-X_{p r e}^{*}\right)^{2}}
$$

In which:

$\chi^{2}$ - chi-square;

$X_{\text {exp }}^{*}$ - humidity ratio experimental by the model; and,

$X_{\text {pre }}^{*}$ - predicted humidity ratio.

\section{Chemical and toxicological determinations}

After dried, the samples were ground with the aid of a willeytype knife mill with the opening of mesh 10,20 , and $32(1.70$ $\mathrm{mm}, 0.85 \mathrm{~mm}, 0.50 \mathrm{~mm}$ ) and analyzed for protein content by determination of the total nitrogen content of the samples by the Micro-Kjeldahl method, using the generic conversion factor of 6.25 to turn the quantified content into percentage of protein (Brazil, 2008). The percentage of lipids was determined based on the extraction of lipids bound to proteins and carbohydrates, as described by Folch et al. (1957). The carbohydrate content was calculated by the centesimal difference of the sum of the percentages of moisture, protein, lipids, and ashes (Brazil, 2008). The percentage of moisture was determined by means of oven drying at $100 \pm 5^{\circ} \mathrm{C}$ for 24 hours (Brazil, 2008). The percentage of ash was determined by incinerating the sample in muffle at $550^{\circ} \mathrm{C}$ until ash became white or slightly grayish (Brazil, 2008). Soluble solids content, in ${ }^{\circ}$ Brix, was determined in a digital refractometer with automatic temperature compensation, from the cellular juice extracted from $100 \mathrm{~g}$ of sample (Met 932.12 from Aoac, 1997). The $\mathrm{pH}$ was determined using a digital $\mathrm{pH}$ meter (Met 981.12 of AOAC, 1997). The titratable acidity content was measured in $5 \mathrm{~g}$ of previously ground 
material and homogenized in $50 \mathrm{ml}$ of distilled water by titration with standard $0.1 \mathrm{M} \mathrm{NaOH}$. The results were expressed as \% of malic acid (Met 981/12 Aoac, 1997). The ascorbic acid content was determined in $5 \mathrm{~g}$ of the material and homogenized in $50 \mathrm{ml}$ of extraction solution prepared with oxalic acid, titrating with 2,6-dichlorophenolindofenol until pink. The results were expressed as mg ascorbic acid per $100 \mathrm{~g}$ of sample (Met 967.21 Aoac, 1997). Toxicological analyzes were performed using the bioassay method composed of Artemia salina (Meyer et al., 1982).

\section{Statistical methods}

The comparison between the treatments was performed through analysis of variance (ANOVA), with regression to the quantitative data, adjusting the equations according to obtaining a higher $R^{2}$ value. The statistical results were analyzed by the ASSISTAT program (Silva and Azevedo, 2002).

\section{Conclusion}

The temperature influenced the flour quality. The flour obtained at the temperature of $55{ }^{\circ} \mathrm{C}$ presented the best chemical percentages and showed no toxic effect. The models studied presented good statistical indices as a function of the adjustments to the experimental data. The Wang and Singh model presented the best $\mathrm{R}^{2}$ and $\chi^{2}$ for the drying kinetics of the palm shoots. The Peleg model presented a unique graphical behavior, reaching to cross the field of negative water quantity, before reaching the equilibrium point of the dehydration process, indicating that this model can not be used to simulate the drying process of palm shoots and 'Miúda' within the temperature range studied.

\section{Acknowledgements}

The Federal University of Paraíba, the Center for Social and Agrarian Sciences and the Course Coordination in Agroindustry.

\section{References}

Association of Official Analytical Chemists. 2005. Official methods of analysis of the Association of Official Analytical Chemists.18th edn. Gaithersburg: AOAC.

Azevedo LC, Silva IRA, Araujo AJB, Oliveira SB, Azoubel P M (2008) Physical-chemical characterization of the mango shell flour cv. Tommy atkins. Paper presented at XXI Brazilian Congress of Food Science and Technology and XV Latin American and Caribbean Seminar on Food Science and Technology, 2008, Belo Horizonte-Brazil, October of 2008

Brazil, National Agency of Sanitary Surveillance (Anvisa). Resolution $n^{\circ} 354$ de 18 june de 1996.

Brazil, National Commission on Standards and Food Standards CNNPA. Resolution CNNPA, $\mathrm{n}^{\circ} 12$ de june 1978.

Brazil. Adolfo Lutz Institute. 2008. Physico-chemical methods for food analysis. 4 ed. São Paulo, Brazil.

Bobbio FO, Bobbio PA. 1995. Introduction to food chemistry. 2 ed. São Paulo, Brazil.

Borba AL 2005 Effect of some operational parameters on physical, physical-chemical and functional characteristics of extrudates of sweet potato flour (Ipomoea batatas). Dissertation, Luiz de Queiroz College of Agriculture. Universidade de São Paulo, Piracicaba, 2005.
Borges AB, Pereira J, Lucena EMP (2009) Characterization of green banana flour. Cienc Tecn Food. 29(2):333-339.

Cavalcante AS, Cavalcante F N, Rangel A H N, Lopes K B P (2011) The forage palm: an alternative to the semi-arid. Rev Gren Agroec Desenv Sustai. 6(3):49-58.

Corrêa PC, Resende O, Martinazzo AP, Goneli ALD, Botelho FM (2007) Mathematical modeling for the description of the bean drying process (Phaseolus vulgaris L.) thin layers. Eng Agríc. 27(2): 501-507.

Farias VFS (2013) Evaluation of development, quality and antioxidant capacity in palm bud (Opuntia sp.) for human consumption. Dissertation, Federal University of Campina Grande, Pombal, 2013.

Fao - food and agriculture organization of the united nations (2001) In: Barbera G, Inglese P, Barrios EP. $1^{\circ}$ edn. Agroecology, cultivation and uses of forage cactus pear. Paraíba-Brazil, 2001.

Formiga AS, Costa FB (2015) Physical, chemical and technological aspects of the dry extract of palm shoots. Paper presented at the XII Congress of scientific initiation of the Federal University of Campina Grande, 2015, Campina Grande-Brazil, June of 2015.

Folch J, Less M, Stanley S (1957) A simple method for the isolation and purification of total lipids from animal tissues. J Biol Chem. 226 (1):497-509.

Gava AJ (2008) Food Technology: Principles and Applications, $1^{\circ}$ edn, São Paulo Brazil, 2008.

Galdino PO, Figueirêdo, RMF, Queiroz, AJM, Galdino, PO (2016) Drying kinetics of atemoya pulp. Rev Bras Eng Agr Amb. 20:672-677.

Gusmão RP (2011) Evaluation of the technological aspects involved in the production of forage palm flour (Opuntia fícus indica Mill). Dissertation, Federal University of Paraíba, João Pessoa, 2011.

Kashaninejad M, Mortazani A, Safekord A, Tabil, LG (2007) Thin-layer drying characteristics and modeling of pistachio nuts. J Food Eng. 78(3):98-108.

Medina-Torres L, Vernon-Carter EJ, Gallegos-Infate JA, Rocha-Gusman NE, Herrera-Valencia E, Calderas F, Jimenéz-Alvarado, R (2011) Study os the antioxidante properties os extractsobtainedfromnopal cactos (Opuntia fícus-indica) cladodesafterconvectivedriying. J Sci Food Agric. 91:1001-1005.

Melo A, Ferreira M, Véras A, Lima LE, Vilela E, Araújo P (2003) Partial replacement of soybean meal by urea and forage palm (Opuntia fícus indica Mill) in diets for lactating first cows Performance. Rev Bras Zootec. 329(3):727-736.

Meyer BN, Ferrigni NR, Putnam JE, Jacobsen LB, Nichols DE, Mclaughlin JL (1982) Brine shrimp, a convenient general bioassy for active-plant constituents. Plant. 45:3134.

Nascimento KF, Teshima E, Silva CMR (2011) Physicochemical characterization of Opuntia ficus-indica cladodes. Paper presented at the XV Seminar on Scientific Initiation (SEMIC). Anais Seminar of Scientific Initiation. Feira de Santana-Brazil, October 2011.

Nguta JM, Mbaria JM, Gathumbi PK, Kabasa JD, Kiama SG (2011) Biological screening of kenya medicinal plants using Artemia salina L. (Artemiidae). Pharmac Onl. 2:458 78.

Ordoñez-Pereda JA (2005) Carbohydrates. In: Food Technology: Food Components and Processes. São Paulo: Artmed, 2005. 63-79.

Pereira EM (2016) Flour production obtained from palm bud. Dissertation, Federal University of Campina Grande, Campina Grande- Brazil, 2016. 
Pereira EM, Leite Filho MT, Mendes FA, Martins ANA, Rocha APT (2015) Potential toxicological front Artemia Salina in condiment plants commercialized in the city of Campina Grande-PB. Rev Gren Agroec Desenv Sustai. 10(1):52-56.

Prette AP (2012) Utilization of pulp and residues of jackfruit (Artocarpus heterophyllus Lam.) By convective drying. Dissertation, Federal University of Campina Grande, Campina Grande- Brazil, 2012.

Portela JVF (2009) Study of the technological and quality aspects involved in the use of watermelon peel and pulp (Citrullus lanatus Schrad). Dissertation, Federal University of Paraíba, João Pessoa, 2009.

Reinolds SG, Arias E (2008) General background onopuntia. Available <http://www.fao.org/DOCREP/005/2808E/y2808e04.htm> Accessed on $20^{\text {th }}$ January 2017.

Reis RC (2002) Evaluation of the quality attributes involved in mango dehydration (Mangifera Indica L.) cv. Dissertation, Federal University of Viçosa, Viçosa-MG, 2002.

Rodrigues E (2006) Drying of pineapple in fixed bed drier. Doctorate, Federal University of Viçosa, Viçosa-MG, 2006.
Hoffmann W (2001) Ethnobotany. In: Agroecology, cultivation and uses of forage cactus pear. 2001

Severo DS, Araújo ADS, Deodato JN, Silva CCM, Alves GS (2015) Preparation and physical chemistry and microbiological characterization of flour palm (Opuntia fícusindica Mill) at different temperatures. Rev Gren Agroec Desenv Sustai. 10(4):30-33.

Silva YC, Silva F D, Silva AS, Lima E E, Souza J A (2004) Application of the Fick and Page models on drying of forage palm (Opuntia fícus indica) in greenhouse. Paper presented at the IV Latin American Meeting of PostGraduation, CD, UNIVAP, São José dos Campos-SP, October 2004

Silva WP, Silva CMDPS (2016) LAB Fit Curve Fitting Software (Nonlinear Regression and Treatment of Data Program) V 7.2.48 (1999-2015), online, available<www.labfit.net>, access on $01^{\text {th }}$ june 2016 .

Silva FASE, Azevedo CAV (2002) Version of the computer program Assistat for the operating system Windows. Rev Bras Prod Agroind. 4(1):71-78.

Sousa HC, Silva NJP, Pereira EM, Silva Filho CRM, Macêdo ALB (2016) Physicochemical and toxicological quality of flour obtained from the central axis of jackfruit. Rev Gren Agroec Desenv Sustai. 11(4):91-98. 